\title{
The weak rupiah: catching the tailwinds and avoiding the shoals
}

\author{
Willem Thorbecke ${ }^{1}$ (D)
}

Published online: 4 September 2020

(c) Institute for Social and Economic Change 2020

\begin{abstract}
The Indonesian rupiah depreciated 50\% between July 2011 and February 2020. Blanchard et al. (Are capital inflows expansionary or contractionary? Theory, policy implications, and some evidence. NBER Working Papers 21619, National Bureau of Economic Research, Cambridge, MA, 2015) showed that capital outflows from emerging markets can reduce output by increasing the cost of financial intermediation and can increase output by increasing net exports. Regression results indicate that Indonesian banks are exposed to depreciations, but that exports are not stimulated by depreciations. The findings also indicate that Indonesia's export price index is positively correlated with commodity prices and negatively correlated with manufactured goods prices. Exporting more manufactures would reduce Indonesia's exposure to volatile commodity prices and allow depreciations to stimulate exports. This paper considers several steps that Indonesia could take to increase its manufacturing exports.
\end{abstract}

Keywords Indonesia $\cdot$ Exchange rate elasticities $\cdot$ Exchange rate exposure $\cdot$ Foreign direct investment $\cdot$ Export diversification $\cdot$ Technology assimilation

JEL Classification F14 · F10

\section{Introduction}

The Indonesian rupiah depreciated 50\% against the U.S. dollar between July 2011 and March 2020. U.S. interest rate hikes and global turmoil acted as pull factors and Indonesian current account deficits and uneven fundamentals acted as push factors to generate capital outflows and weaken the currency. Blanchard et al. (2015) showed that outflows can depreciate exchange rates and increase net exports and output. Outflows from emerging markets can also increase the cost of financial intermediation and reduce output.

Capital outflows during the 1997-1998 Asian Crisis depreciated the rupiah from 2400 per dollar to 15,000 per dollar, eroding bank capital and reducing financial intermediation.

Willem Thorbecke

willem-thorbecke@ rieti.go.jp

1 Research Institute of Economy, Trade and Industry and Center for International Development, 1-3-1 Kasumigaseki, Chiyoda-ku, Tokyo 100-8901, Japan 
Indonesian banks faced a mismatch between rupiah assets and foreign currency liabilities (Yoshitomi 2003). As the rupiah weakened, bank capital shrank. According to data from Bank Indonesia, deposits and lending by private domestic banks fell by almost $20 \%$ during the crisis (see Azis and Thorbecke 2004). This disintermediation contributed to Indonesia's $14 \%$ drop in GDP in 1998.

This paper investigates how the rupiah affects the banking sector and the Indonesian economy. To do this, it first examines how the rupiah/dollar exchange rate affects industry and aggregate stock returns. Standard finance models hold that stock prices equal the expected present value of future net cash flows, implying that stock prices provide information about future economic activity. The results indicate that stocks in the aggregate are exposed to a rupiah depreciation. A $1 \%$ depreciation will cause aggregate returns to fall by almost $1 \%$. Looking at individual sectors, only five out of 62 individual sectors are exposed to depreciations. Of these five, three are in the banking sector. These results indicate that the weakening rupiah reduces bank profitability.

Unlike during the Asian Financial Crisis, during the 5 years before the Coronavirus hit Indonesian banks earned high profits, possessed abundant liquidity, and had an aggregate capital adequacy ratio (CAR) exceeding 23\% (IMF 2018). Even after the crisis started, banks maintained a CAR of $21.7 \%$ during the first quarter of 2020 (World Bank 2020). However, $71 \%$ of bank loans go to corporations, and $45 \%$ of corporate debt is denominated in foreign currency (IMF 2018). Banks are thus exposed to exchange rate depreciations through their corporate loans and corporations are directly exposed to depreciations. The Indonesian government should promote sound risk management practices such as requiring banks to hold sufficient liquid foreign currency assets to meet extraordinary foreign exchange needs over a 30-day period (BIS 2013) and extending corporate prudential foreign exchange regulations to all corporate foreign exchange liabilities (IMF 2018).

Does a rupiah depreciation have the offsetting benefit that Blanchard et al. (2015) highlighted of stimulating exports? To investigate this question this paper employs both times series and panel data methods. Both approaches indicate that a weaker exchange rate will not increase Indonesia's exports. One reason for this is that half of Indonesia's exports are food, agricultural products, minerals, energy and other primary products. These goods are often denominated in U.S. dollars. A depreciation of the rupiah is associated with an appreciation of the U.S. dollar. When the dollar appreciates, the prices of primary products in terms of the importing countries' currencies increase and they import less. This offsets the price competitiveness gains that manufactured products receive from depreciations.

Indonesia's three leading export categories are vegetable oil, coal, and crude oil. As Fig. 1 shows, the value of these exports rose before the 2008 Global Financial Crisis as commodity prices rose and tumbled after 2012 as commodity prices fell. Depending on primary exports thus exposes Indonesia to changes in world commodity prices. To investigate how diversification could reduce the impact of these price shocks, this paper examines the correlations between Indonesia's aggregate export price and world prices for individual goods. It finds large positive correlations between Indonesia's export prices and the prices of primary products such as iron, steel, aluminum, natural gas, paper, copper, and rubber. It also finds negative correlations between Indonesia's export prices and the prices of both electronics goods such as computers, computer parts, cell phones, integrated circuits, televisions, and cameras and of labor-intensive manufactures such as textiles, apparel, toys, and footwear. Exporting more manufacturing products would thus reduce Indonesia's exposure to negative terms of trade shocks.

This paper considers how Indonesia can increase its manufacturing exports. It recommends that Indonesia follow Malaysia, Thailand, and Vietnam and attract foreign direct 
Fig. 1 The value of exports for Indonesia's three leading export categories. Notes: The international standard industrial classification codes for these products are 1514 for vegetable oils, 1010 for coal, and 1110 for crude oil. Source: CEPII-CHELEM database

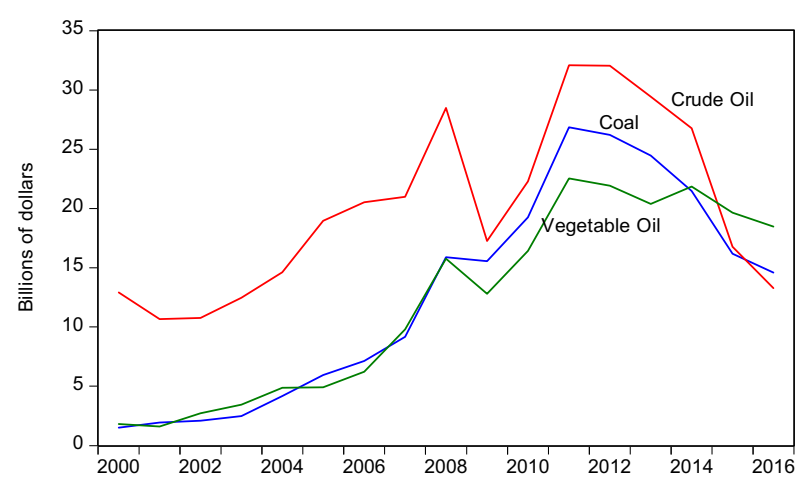

investment (FDI) from multinational corporations (MNCs) seeking efficient export platforms. Indonesia could pursue FDI by improving electricity supply, fighting corruption, reducing onerous severance pay requirements, resisting protectionism that increases the cost of imported inputs, investing in human capital and encouraging entrepreneurship. Now is an opportune time to focus on this strategy, as MNCs are seeking to diversify production out of China.

The next section examines the exposure of Indonesian industries to exchange rates. The following sections investigate how exchange rates affect exports and how Indonesia could reduce its exposure to terms-of-trade shocks. The penultimate section considers how Indonesia could increase its manufacturing exports and the final section concludes.

\section{The exchange rate exposure of Indonesian sectors}

\section{Data and methodology}

It is possible to examine how exchange rates affect industries by estimating the exchange rate exposures of stocks in individual sectors. Economic theory indicates that there is a strong link between stock prices and economic activity. Standard finance models hold that stock prices equal the expected present value of future net cash flows. Shapiro (1988) noted that these cash flows depend on real activity. Black (1987, p. 113) observed that "the sector-by-sector behavior of stocks is useful in predicting sector-by-sector changes in output, profits, or investment. When stocks in a given sector go up, more often than not that sector will show a rise in sales, earnings, and outlays for plant and equipment." Barro (1990), Schwert (1990), Velinov and Chen (2015), Liu et al. (2007), and others reported strong links between stock prices and variables such as investment, production, and earnings. When the rupiah falls, industries that benefit from a depreciation should see their stock prices rise and industries that are harmed should see their prices fall.

There is a large literature investigating exchange rate exposures (see, e.g., Dominguez and Tesar 2006, or Jayasinghe and Tsui 2008). The capital asset pricing model implies that individual and sectoral returns can be explained by the return on the aggregate stock market and that no other variables are needed. The exchange rate exposure research has found that exchange rate changes often have additional explanatory power for sector-specific returns. In this framework industry stock returns $\left(\Delta R_{i, t}\right)$ are regressed on changes in aggregate stock 
market returns $\left(\Delta R_{M, t}\right)$ and exchange rate changes $\left(\Delta e_{t}\right)$. Thorbecke (2019) found that oil prices matter for some Indonesian sectors and the World Bank (2020) reported that the American market is important for Indonesian exporters. To capture these last two influences, oil price changes and the return on the U.S. stock market are included in the regression. ${ }^{1}$ Following standard multifactor models in finance, the assumption is that the causality goes from the macroeconomic variables to the individual portfolios (see, e.g., Chen et al. 1986, and McElroy and Burmeister 1988).

In this paper a four factor model is estimated, with $\Delta R_{i, t}$ a function of $\Delta e_{t}, \Delta R_{M, t}$, the change in the price of crude oil $\left(\Delta c r u d e_{t}\right)$, and the change in the aggregate U.S. stock market return $\left(\Delta R_{U S, M, t}\right)$ :

$$
\Delta R_{i, t}=\alpha_{i}+\beta_{i, e} \Delta e_{t}+\beta_{i, M} \Delta R_{M, t}+\beta_{i, c r u d e} \Delta c r u d e_{t}+\beta_{i, U S, M} \Delta R_{U S, M, t}+\varepsilon_{i, t} .
$$

Augmented Dickey-Fuller tests allow rejection of the null hypothesis that these series have unit roots. Ordinary least squares estimation is thus used to estimate Eq. (1).

Data on returns on individual sectors and the market portfolio in Indonesia and on the market portfolio in the U.S. come from the Datastream database. ${ }^{2}$ The monthly change in the natural logarithm of stock prices is employed. Data on the monthly change in the log price of West Texas Intermediate crude oil also come from Datastream. Data on the monthly change in the log rupiah/dollar exchange rate are obtained from the CEIC database. The sample period for the estimation extends from January 2000 to June 2018.

\section{Results}

Before turning to the results from estimating Eq. (1), the findings with aggregate Indonesian stock returns as the dependent variable are considered:

$$
\Delta R_{M, t}=0.0083 * *-0.91 * * * \Delta e_{t}+0.046 \Delta \text { crude }_{t}+0.50 * * * \Delta R_{U S, M, t}+\varepsilon_{i, t}
$$

(0.039)

Adjusted R-squared $=0.429$, Standard error of regression $=0.051$, Sample period $=2000 \mathrm{M} 01-2018 \mathrm{M} 06$. Heteroscedasticity and autocorrelation consistent standard errors in parentheses). $* * *(* *)$ denotes significance at the $1 \%(5 \%)$ levels.

The findings indicate that the aggregate Indonesian stock market is very exposed to the rupiah/dollar exchange rate. A $1 \%$ depreciation of the rupiah would decrease the return on the Indonesian stock market by $0.91 \%$. These results indicate that depreciations exert a negative impact on economic activity in Indonesia.

To understand why, we can examine how individual sectors are affected. Stock returns on 62 sectors are regressed on the variables in Eq. (1). Those sectors whose exchange rate exposures are statistically significant at least the $10 \%$ level are reported in Table 1.

The table indicates that the real estate sector benefits from depreciations. As the ADB (2018) noted, currency depreciations increase real estate prices in Asia by increasing demand from those who can access sources of foreign currency. The table also indicates

\footnotetext{
1 Omitted variable bias should not be a serious problem in these regressions, since two additional variables are added to the two variables (the change in the exchange rate and the return on the market portfolio) that have been used in hundreds of published studies.

${ }^{2}$ For the individual sectors, Datastream categorizes publicly traded companies in Indonesia into 62 industry categories and sub-categories. These 62 sectors are used as the left hand side variables in the regression.
} 
Table 1 The exposure of industry stock returns to exchange rates and other variables

\begin{tabular}{|c|c|c|c|c|}
\hline (1) & (2) & (3) & (4) & $(5)$ \\
\hline Sector & Exchange rate beta & $\begin{array}{l}\text { Indonesian } \\
\text { market } \\
\text { beta }\end{array}$ & Crude oil beta & U.S. market beta \\
\hline \multirow[t]{2}{*}{ Real estate holding and dev. } & $0.695^{*}$ & $1.46^{* * * *}$ & $-0.208 *$ & -0.147 \\
\hline & $(0.376)$ & $(0.242)$ & $(0.117)$ & $(0.439)$ \\
\hline \multirow[t]{2}{*}{ Real estate } & $0.694 *$ & $1.46^{* * * *}$ & $-0.208 *$ & -0.149 \\
\hline & $(0.377)$ & $(0.242)$ & $(0.117)$ & $(0.439)$ \\
\hline \multirow[t]{2}{*}{ Real estate investment services } & $0.693 *$ & $1.46^{* * *}$ & $-0.209 *$ & -0.142 \\
\hline & $(0.376)$ & $(0.243)$ & $(0.118)$ & $(0.440)$ \\
\hline \multirow[t]{2}{*}{ Brewers } & $0.414^{*}$ & 0.159 & 0.137 & 0.125 \\
\hline & $(0.233)$ & $(0.103)$ & $(0.089)$ & $(0.194)$ \\
\hline \multirow[t]{2}{*}{ Beverages } & $0.414^{*}$ & 0.159 & 0.137 & 0.125 \\
\hline & $(0.233)$ & $(0.103)$ & $(0.089)$ & $(0.194)$ \\
\hline \multirow[t]{2}{*}{ Tobacco } & $0.349 * *$ & $0.962 * * *$ & -0.075 & $-0.280 * *$ \\
\hline & $(0.176)$ & $(0.096)$ & $(0.061)$ & $(0.132)$ \\
\hline \multirow[t]{2}{*}{ Personal and household goods } & $0.244 * *$ & $0.792 * * *$ & -0.093 & -0.248 \\
\hline & $(0.125)$ & $(0.082)$ & $(0.046)$ & $(0.090)$ \\
\hline \multirow[t]{2}{*}{ Consumer staples } & $0.193 * *$ & $0.942 * * *$ & -0.0457 & -0.283 \\
\hline & $(0.093)$ & $(0.057)$ & $(0.040)$ & $(0.080)$ \\
\hline \multirow[t]{2}{*}{ Financial } & $-0.260 * *$ & $0.997 * * *$ & -0.033 & 0.092 \\
\hline & $(0.105)$ & $(0.071)$ & $(0.047)$ & $(0.076)$ \\
\hline \multirow[t]{2}{*}{ Banks } & $-0.294 * *$ & $0.997 * * *$ & -0.0300 & 0.097 \\
\hline & $(0.112)$ & $(0.079)$ & $(0.050)$ & $(0.086)$ \\
\hline \multirow[t]{2}{*}{ Construction and materials } & $-0.313 * *$ & $0.984 * * *$ & -0.038 & -0.110 \\
\hline & $(0.136)$ & $(0.096)$ & $(0.051)$ & $(0.106)$ \\
\hline \multirow[t]{2}{*}{ Building materials fixtures } & $-0.334 * *$ & $0.984 * * *$ & -0.037 & -0.127 \\
\hline & $(0.149)$ & $(0.099)$ & $(0.055)$ & $(0.110)$ \\
\hline \multirow[t]{2}{*}{ Mortgage finance } & $-0.944 * *$ & $1.36^{* * * *}$ & -0.054 & 0.000 \\
\hline & $(0.455)$ & $(0.252)$ & $(0.079)$ & $(0.304)$ \\
\hline
\end{tabular}

The table reports the results from regressing industry stock returns on the rupiah/dollar exchange rate (column 2), the return on the Indonesian aggregate stock market (column 3), the log change in the price of West Texas Intermediate crude oil (column 4), and the return on the aggregate U.S. market (column 5). Heteroscedasticity and autocorrelation consistent standard errors are in parentheses

that three of the five industries that are harmed by rupiah depreciations are in the financial sector. Most harmed of all is mortgage finance, with a $1 \%$ depreciation reducing stock returns by $0.94 \%$.

Haswidi (2018) reported that the Indonesian Central Bank (BI) has to raise interest rates when the rupiah is weak and that mortgage lenders pass on the bulk of these interest rate increases to consumers. This in turn reduces consumers' demand for mortgages and reduces the quantity of loans and the profitability of mortgage lenders.

However, the exchange rate affects the aggregate economy and mortgage lenders apart from its induced effect on BI policy. Over the last few years BI has used the 7-day reverse repo rate (Repo) as its policy instrument. Before this it used the rate on 1-month BI Certificates (SBI). The BI Deposit Facility Rate (BID) is available over a longer 
sample period than Repo or SBI and closely correlated with both. The correlation coefficient between the change in Repo and BID equals 0.90 and the correlation coefficient between the change in SBI and BID equals 0.73. Regressing the return on the aggregate market and on mortgage finance stocks (Morfin) on BID and the variables employed above yields the following:

$$
\begin{aligned}
\Delta R_{M, t}= & 0.0099 * * *-0.99 * * * \Delta e_{t}-0.014 \Delta \text { crude }_{t}+0.51 * * * \Delta R_{U S, M, t}-0.035 * * B I D+\varepsilon_{i, t} \\
& (0.0032) \\
(0.11) & (0.051)
\end{aligned}
$$

Adjusted R-squared $=0.567$, Standard error of regression $=0.040, \quad$ Sample period $=2005 \mathrm{M} 11-2018 \mathrm{M} 06$. Heteroscedasticity and autocorrelation consistent standard errors in parentheses). $* * *(* *)$ denotes significance at the $1 \%(5 \%)$ levels.

$$
\begin{aligned}
& \Delta \text { Morfin }=0.0035-0.91 * * e_{t}-0.056 \Delta \text { crude }_{t}+1.34 * * * \Delta R_{M, t}+0.03 \Delta R_{M U S, M, t}-0.022 B I D+\varepsilon_{i, t} \\
& \begin{array}{llllll}
(0.0090) & (0.45) & (0.080) & (0.26) & (0.29) & (0.060)
\end{array}
\end{aligned}
$$

Adjusted R-squared $=0.399$, Standard error of regression $=0.084$, Sample period $=2010 \mathrm{M} 01-2018 \mathrm{M} 06$. Heteroscedasticity and autocorrelation consistent standard errors in parentheses). $* * *(* *)$ denotes significance at the $1 \%(5 \%)$ levels.

The results using Repo are similar, although the sample period is much shorter. These findings indicate that, controlling for interest rates, a one hundred basis point change in exchange rates still leads to almost a one hundred basis point change in the returns on the aggregate market and on mortgage finance stocks.

These results imply that the weakening rupiah reduces corporate and bank profitability. It thus reduces corporations and banks' ability to increase capital from earnings. Azis and Thorbecke (2004) found over an earlier period that exchange rate depreciations reduced capital at Indonesian banks. They argued that improved risk management practices would help Indonesian banks to weather exchange rate shocks.

Before the COVID-19 crisis, Indonesian banks' aggregate CAR exceeded 23\% (IMF 2018). As discussed above, though, they were exposed to depreciations because $71 \%$ of their loans flowed to corporations and $45 \%$ of corporate debt was denominated in foreign currency (IMF 2018).

The experience of the Asian Financial Crisis teaches that it is important that the Indonesian government eliminate any associated moral hazard. As Azis (2018) noted, improvements in corporate resolution frameworks and bankruptcy regimes are needed. The government could incentivize bankers to manage these risks well by stating that they would not bail out owners and managers who suffer due to foreign exchange losses. In addition, it should promote sound risk management knowledge and techniques. For instance, it could require banks to hold sufficient liquid foreign currency assets to meet extraordinary foreign exchange needs over a 30-day period (BIS 2013). It could also extend corporate prudential foreign exchange regulations concerning hedging foreign exchange risk and maintaining sufficient foreign exchange assets to all corporate foreign exchange liabilities (IMF 2018).

The pandemic has also generated a new set of challenges (World Bank 2020). As firms and households lose incomes, their ability to repay loans decreases. This can reduce the quality of banks' assets and weaken their balance sheets. The government has promoted loan restructuring, provided banks with liquidity, and subsidized interest rates. As the World Bank (2020) argued, it needs to encourage banks to use this relief to intermediate funds without supporting "zombie" firms. 


\section{Exports and exchange rates}

\section{Data and methodology}

The imperfect substitutes model is used to estimate trade elasticities. In this framework export functions can be written as:

$$
e x_{t}=\alpha_{1}+\alpha_{2} \text { reer }_{t}+\alpha_{3} y_{t}^{\prime}+\varepsilon_{t},
$$

where $e x_{t}$ represents real exports, reer $_{t}$ represents the real exchange rate, $y_{t}^{\prime}$ represents foreign real income, and all variables are measured in natural logs.

Equation (2) is derived from a partial equilibrium framework where exchange rate and income are taken as given. For this reason, care must thus be exercised in interpreting the parameters. Chinn $(2004,2005)$ employed this framework to investigate U.S. exports. He treated Eq. (2) as a "semi-reduced form" model and interpreted the resulting parameter estimates as structural. As an example, he employed the estimated coefficients to investigate whether the Marshall-Lerner condition applies to the U.S. This paper follows Chinn in attaching a structural interpretation to the parameters. It estimates the trade elasticities first using time series data and then using panel data.

Time series data on the volume of Indonesia's exports to the world come from the Central Bureau of Statistics (CBS) via the CEIC database. Data on the Indonesian real effective exchange rate come from the Bank for International Settlements.

Rest of the world income $\left(y_{t}{ }^{\prime}\right)$ is calculated by employing a geometrically weighted average of income changes in Indonesia's top nine export destinations. The index is constructed using the following formula:

$$
y_{t}^{\prime}=y_{t-1}^{\prime} \Pi_{i}\left(y_{i, t} / y_{i, t-1}\right)^{w(i, t)},
$$

where $y_{i, t}$ represents GDP in importing country $i$ in quarter $t$ and $w(i, t)$ represents the value of Indonesia's exports going to country $i$ in quarter t relative to the value of Indonesia's exports going to all nine leading importers. The weights in Eq. (3) are calculated using annual data on Indonesia's exports to the leading importers obtained from the CEPIICHELEM database. The annual data on the weights $(w(i, t))$ are converted to quarterly data using linear interpolation. The underlying GDP data used in Eq. (1) are quarterly, as are the export and exchange rate data.

The Indonesian real effective exchange rate experienced wild fluctuations during the 1997-1998 Asian Financial Crisis. This was also a time when other factors such as the unwillingness of importers to accept letters of credit from Indonesian banks hampered Indonesia's exports. To prevent this from clouding inference, the sample period begins in 1999Q1 and extends to 2018Q2.

Augmented Dickey-Fuller indicate that the series are integrated of order one. The Schwarz Criterion is used to test for the number of lags in the unconstrained vector autoregression. The trace statistic permits rejection of the null hypothesis of no cointegrating relations between exports and the real exchange rate and real GDP against the alternative hypothesis of one cointegrating relation at the $3 \%$ level and the maximum eigenvalue statistic permits rejection of the null at the $9 \%$ level. Dynamic ordinary least squares estimation, a technique for estimating cointegrating relations, is this employed. 
For the panel data estimation, Eq. (2) is used again. Minor importing countries are excluded from the sample, since these can have large percentage changes in imports from Indonesia due to idiosyncratic factors rather than macroeconomic variables. ${ }^{3}$

Data on exports are measured in U.S. dollars and obtained from the CEPII-CHELEM database. They are deflated using an Indonesian export price deflator measured in dollars and obtained from the Indonesian CBS via the CEIC database. Export data from CEPIICHELEM extend to 2016 and the export price data from CBS begin in 2000.

Data on bilateral real exchange rates between the exporting and importing countries and real GDP in the importing countries are also obtained from the CEPII-CHELEM database. An increase in the real exchange rate represents an appreciation of the exporting country's currency.

A battery of panel unit root tests and Kao (1999) cointegration tests point to cointegrating relations among the variables. Therefore, Mark-Sul weighted DOLS techniques are used. The estimated equation takes the form:

$$
\begin{gathered}
\operatorname{ex}_{i, j, t}=\beta_{0}+\beta_{1} \operatorname{rer}_{i, j, t}+\beta_{2} y_{j, t}^{*}+\sum_{k=-p}^{p} \alpha_{1, j, k} \Delta \operatorname{rer}_{i, j, t-k}+\sum_{k=-p}^{p} \alpha_{2, j, k} \Delta y_{j, t-k}^{*}+u_{i, j, k}, \\
t=1, \ldots T ; \quad j=1, \ldots N
\end{gathered}
$$

where $e x_{i, j, t}$ represents real exports from Indonesia to country $j$ in year $t$, rer $_{i, j, t}$ represents the bilateral real exchange rate between Indonesia and country $j$, and $y_{j, t} *$ represents real GDP in country $j$.

One lag and one lead of the first differenced independent variables are included to correct for endogeneity and serial correlation. A sandwich estimator is employed to allow for heterogeneity in the long-run residual variances. Country fixed effects are also included.

\section{Results}

The time series results, with heteroscedasticity and autocorrelation consistent standard errors in parentheses, are:

$$
\text { ex }_{t}=0.35 *+0.68 \text { reer }_{t}+1.59 * * * y_{t}^{\prime}+\cdots
$$

$$
(0.20) \quad(0.55) \quad(0.36)
$$

Adjusted R-squared $=0.772$, Standard error of regression $=0.192, \quad$ Sample period $=1999$ Q1-2017Q4, Seasonal dummies and two leads and four lags of first differenced independent variables included. $* * *(*)$ denotes significance at the $1 \%(10 \%)$ levels.

The coefficient on the real effective exchange rate is of the unexpected sign, though not statistically significant. There is thus no evidence that a weaker exchange rate would increase Indonesia's exports. The coefficient on rest of the world GDP is of the expected sign and statistically significant at the $1 \%$ level. The results indicate that a $10 \%$ increase in rest of the world GDP would increase Indonesia's exports by $15.9 \%$.

The results, with standard errors in parentheses, are:

\footnotetext{
${ }^{3}$ The importing countries employed are Australia, China, France, Germany, Hong Kong, India, Italy, Japan, Malaysia, the Netherlands, the Philippines, Saudi Arabia, South Korea, Spain, Taiwan, Thailand, the United Kingdom, the United States, and Vietnam.
} 
Table 2 Share of exports of selected ASEAN countries by sector, 2016. Source: CEPII-CHELEM database

\begin{tabular}{llccc}
\hline & Indonesia $(\%)$ & Malaysia $(\%)$ & Thailand $(\%)$ & Vietnam $(\%)$ \\
\hline Manufacturing & 50 & 75 & 76 & 85 \\
Food \& Agriculture & 21 & 9 & 15 & 12 \\
Energy & 21 & 13 & 3 & 2 \\
Mining and Others & 7 & 3 & 9 & 9 \\
\hline
\end{tabular}

$$
e x_{t}=0.43 * * * \text { reer }_{t}+1.67 * * * y_{t} *+\cdots
$$

(0.09) (0.10)

Adjusted R-squared $=0.961$, Standard error of regression $=0.196$, Sample period $=2001-2016$, One lag and one lead of the first differenced independent variables included. $* * *$ denotes significance at the $1 \%$ level.

The coefficient on the real exchange rate is again of the unexpected sign. It is also statistically significant in this specification. It indicates that a $10 \%$ depreciation of the rupiah is associated with a $4.3 \%$ decrease in exports. One reason why the coefficient takes on the wrong sign is that one-half of Indonesia's exports are primary products, and these are often denominated in U.S. dollars. An appreciation of the rupiah is associated with a depreciation of the U.S. dollar. When the dollar depreciates, the prices of primary products in terms of the importing countries' currencies decrease and they import more.

The coefficient on rest of the world GDP is of the expected sign and statistically significant at the $1 \%$ level. The results indicate that a $10 \%$ increase in rest of the world GDP would increase Indonesia's exports by $16.7 \%$. These panel data findings and the time series evidence indicate that a slowdown in importing countries would cause a large drop in Indonesia's exports.

An important implication of these results is that a weakening of the rupiah would not stimulate exports. There is a body of evidence indicating that labor-intensive manufacturing exports from Asia are sensitive to exchange rates (see, e.g., Baiardi and Bianchi 2019, and Thorbecke and Salike 2020). If Indonesia diversified its export basket to include more labor-intensive manufactured goods, it might allow exports to increase more from rupiah depreciations. The next section presents evidence that diversifying into manufactures could also reduce Indonesia's exposure to terms of trade shocks.

\section{Diversifying the export basket}

\section{Data and methodology}

As Table 2 shows, one-half of Indonesia's exports are food, agricultural products, mining, energy and other primary products. The table also shows that this is much more than for Indonesia's ASEAN neighbors. Figure 1 plots the value of exports for Indonesia's three leading categories. These are, with International Standard Industrial Classification codes in parentheses: vegetable oil (1514), coal (1010), and crude oil (1110). The figure shows that the value of all three categories rose before the 2008 Global Financial Crisis as commodity prices rose and tumbled after 2012 as commodity prices fell. Depending on primary exports thus exposes Indonesia to changes in world commodity prices. To investigate how 
diversification can reduce the effect of price shocks, this section examines the correlation between world prices for individual goods and Indonesia's export prices.

Finance theory teaches that assets whose returns are uncorrelated or negatively correlated with the overall market portfolio offer diversification benefits (see Ross et al. 2018). When the overall market falls, uncorrelated or negatively correlated assets tend to maintain their value or even increase. In the same way, categories of goods whose prices are uncorrelated or negatively correlated with Indonesia's overall export price index offer diversification benefits.

World prices are proxied by import prices into the U.S., since the U.S. is the largest importer in the world and since the U.S. Bureau of Labor Statistics (BLS) provides long time series for import prices. Correlation coefficients between Indonesian aggregate export prices (measured in dollars) and U.S. import prices (also measured in dollars) are calculated. Data on Indonesian export prices are obtained from the CEIC database and data on U.S. import prices are obtained from the BLS.

Monthly data on Indonesia's export prices in dollars are available from 2000 until 2018. For most product categories reported in Table 3, price data are available over the same sample period. In a few cases, the starting point for the data is 2002 or 2003.

\section{Results}

The results in Table 3 indicate that world prices for many types of electronics goods are negatively correlated with Indonesia's export prices. This applies for computers, computer parts, cell phones, integrated circuits, televisions, and cameras. Thus, exporting more electronics goods would provide an opportunity for Indonesian to diversify away risks associated with decreases in commodity prices. Table 3 also indicates that prices for many laborintensive products such as textiles, apparel, toys, and footwear are negatively correlated with Indonesia's export prices. Exporting more labor-intensive manufactures would thus help the Indonesian economy to reduce its exposure to negative price shocks.

On the other hand, Table 3 indicates that there are large positive correlations between the prices for many primary products and Indonesia's export prices. These products include iron, steel, aluminum, natural gas, paper, copper, and rubber. Commodity prices tend to increase and decrease together. When they are increasing, the value of Indonesia's exports rise. When they are decreasing, the value falls. Relying on commodities thus leads to volatility in exports and thus in GDP growth.

\section{Increasing manufacturing exports}

The results above indicate that the prices of both electronics exports and labor-intensive manufactures are negatively correlated with Indonesia's aggregate export prices. Exporting more of these manufactured goods would help Indonesia to weather adverse terms of trade shocks.

For Asian countries Thorbecke (2018) found that a weaker exchange rate increases the depth of a country's electronics supply chain and Thorbecke and Salike (2020) reported that a weaker exchange rate increases a country's labor-intensive exports. Indonesia could harness the tailwind provided by rupiah weakness to increase manufacturing exports.

China, Malaysia, the Philippines, Thailand, Vietnam are integral parts of electronics supply chains but Indonesia is not. Figure 2 shows that Indonesia has not kept pace with 
Table 3 Correlation coefficients between Indonesian aggregate export prices and world prices for individual product categories

\begin{tabular}{|c|c|c|}
\hline HS Code & Corr. Coeff. & Product category \\
\hline 8473 & -0.3428 & Parts and accessories for computers and other office machines \\
\hline 8471 & -0.3041 & Computer equipment \\
\hline 8525 & -0.267 & $\begin{array}{l}\text { Radio \& TV transmission apparatus; video cameras \& camera recorders; TV } \\
\text { cameras }\end{array}$ \\
\hline 6203 & -0.2362 & Men or boys suits, ensembles, suit-type jackets, blazers \& trousers \\
\hline 8517 & -0.2344 & Electrical apparatus for line telephony or line telegraphy; videophones; parts \\
\hline 8527 & -0.2116 & Radio receivers whether or not w/clock, player or recorder in the same housing \\
\hline 8542 & -0.1891 & Electronic integrated circuits and micro assemblies; parts thereof \\
\hline 8528 & -0.1493 & TV reception apparatus; video monitors \& video projectors \\
\hline 63 & -0.1123 & Made up or worn textile articles \\
\hline 9018 & -0.1106 & Instruments/appliances used in medical, surgical, dental, veterinarian sciences \\
\hline 29 & -0.0488 & Organic Chemicals \\
\hline 95 & -0.0462 & Toys, games and sports equipment; parts and accessories thereof \\
\hline 9503 & -0.0389 & Toys; models; puzzles; parts and accessories thereof \\
\hline 62 & -0.0297 & Articles of apparel and clothing accessories, not knitted or crocheted \\
\hline 88 & -0.0272 & Aircraft, spacecraft, and parts thereof (Dec. $2002=100)$ \\
\hline 64 & 0.0148 & Footwear and parts of such articles \\
\hline 6403 & 0.0352 & Footwear with uppers of leather \\
\hline 9405 & 0.046 & Lamps, lighting fixtures, \& illuminated signs and parts thereof \\
\hline 61 & 0.0647 & Articles of apparel and clothing accessories, knitted or crocheted \\
\hline 8409 & 0.0789 & Parts for spark-ignition and diesel internal combustion piston engines \\
\hline 90 & 0.0797 & optical, photographic, medical and measuring instruments \\
\hline 96 & 0.1181 & Miscellaneous manufactured articles \\
\hline 9401 & 0.1379 & Seats other than barber dental and similar \\
\hline 9021 & 0.1391 & Orthopedic appliances; artificial body parts; hearing aids, etc. \\
\hline 7102 & 0.1429 & Diamonds, whether or not worked, but not mounted or set \\
\hline 8411 & 0.1464 & Turbojets, turbopropellers and other gas turbines, and parts thereof \\
\hline 42 & 0.1566 & Articles of leather; travel goods, bags, etc., of various materials \\
\hline 70 & 0.157 & Glass and glassware \\
\hline 91 & 0.1601 & Clocks and watches and parts thereof \\
\hline 9403 & 0.1697 & Furniture other than seats, \\
\hline 8536 & 0.1762 & Electrical circuit switching, protecting or connection app. of 1000 volts or less \\
\hline 8504 & 0.1927 & Electrical transformers, inductors \& static converters (rectifiers); parts \\
\hline 8483 & 0.2005 & Parts for transmitting power (clutches, shafts, gears \& boxes, pulleys, etc.) \\
\hline 8516 & 0.2047 & Electrothermic domestic appliances; water \& space heaters; resistors \\
\hline 2709 & 0.2055 & Petroleum oils and oils from bituminous minerals, crude \\
\hline 82 & 0.2215 & Tools, implements, cutlery, spoons and forks, of base metal; parts thereof \\
\hline 8703 & 0.2284 & Motor vehicles designed to transport people \\
\hline 87 & 0.2305 & Motor vehicles and their parts \\
\hline 8708 & 0.242 & Parts of tractors, buses, automobiles, trucks, spec. vehicles \\
\hline 9506 & 0.2424 & Articles \& equipment for sports; parts \& accessories thereof \\
\hline 94 & 0.2556 & Furniture \& stuffed furnishings; lamps \& lighting fittings, prefab bldgs \\
\hline 8413 & 0.2849 & Pumps for liquids; liquid elevators; parts thereof \\
\hline 69 & 0.2903 & Ceramic products \\
\hline
\end{tabular}


Table 3 (continued)

\begin{tabular}{lll}
\hline HS Code & Corr. Coeff. & Product category \\
\hline 7108 & 0.2921 & Gold (incl plated with platinum), unwrght, semi-mfg or pwdr \\
8501 & 0.315 & Electric motors and generators (excludes generating sets) \\
83 & 0.3488 & Miscellaneous articles of base metal \\
8431 & 0.3566 & Parts for materials handling \& construction machines \\
40 & 0.3685 & Rubber and Articles Thereof \\
8481 & 0.3709 & Taps, cocks, valves \& similar appliances; parts thereof \\
74 & 0.3896 & Copper and articles thereof \\
48 & 0.4713 & Paper and paperboard; articles of paper pulp, paper or paperboard \\
73 & 0.4718 & Articles of iron or steel \\
76 & 0.4836 & Aluminum and articles thereof \\
27 & 0.4939 & Mineral fuels, oils and residuals, bituminous substances and mineral waxes \\
8414 & 0.4952 & Air or vacuum pumps, compressors and fans; vent \& recycling hoods; parts \\
2711 & 0.5006 & Petroleum gases and other gaseous hydrocarbons \\
7601 & 0.5416 & Aluminum, unwrought \\
72 & 0.5925 & Iron and steel \\
\hline
\end{tabular}

Notes: The table reports the correlation coefficients between Indonesia's aggregate export prices, measured in U.S. dollars, and world prices for individual product categories measured in U.S. dollars. World prices are proxied by U.S. import prices for the individual product category. HS Code represents the Harmonized System product code and Corr. Coeff. represents the correlation coefficient. Source: U.S. Bureau of Labor Statistics, CEIC Database, and calculations by the author

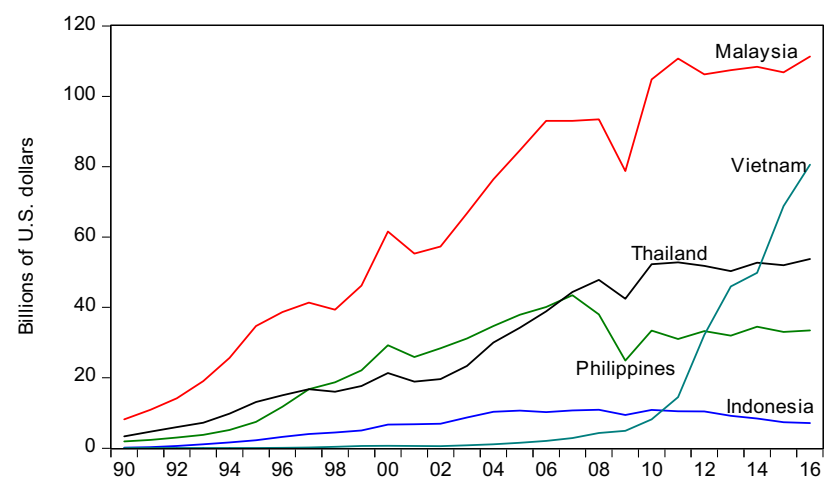

Fig. 2 The value of electronics exports from selected ASEAN countries. Notes: Electronics goods according to the CEPII-CHELEM database come from the following categories: precision instruments, clockmaking, optics, electronic components, consumer electronics, telecommunications equipment, and computer equipment Source: CEPII-CHELEM database

its ASEAN neighbors in electronics exports. Its neighbors initially increased electronics exports by attracting FDI from multinational corporations seeking efficient export platforms. Over time, this vertical FDI led to the formation of industrial clusters and the transfer of knowledge to local firms. 


\section{Attracting FDI and assimilating technology}

As occurred in China and in other ASEAN countries, attracting vertical FDI could help Indonesia to join the electronics value chain. Obtaining FDI is important for Indonesia, as FDI fell 50\% between 2015 and 2018 and Indonesia now finances current account deficits largely through volatile portfolio capital inflows rather than through more stable FDI (ADB 2018). ${ }^{4}$ How could Indonesia obtain more vertical FDI? Jones and Kierzkowski (1990) modeled what causes firms to fragment production. They demonstrated that firms slice up the value chain when the service cost of linking geographically separated production blocks is less than the production cost savings arising from fragmentation. ${ }^{5}$ For instance, a Korean electronics company deciding on whether to move final assembly to Indonesia needs to compare costs for activities such as shipping parts to Indonesia with cost savings from factors such as lower labor costs in Indonesia. If the costs of linking production blocks are lower than the cost savings, the firm will fragment production. Thus, lowering the service link cost or increasing the production cost savings will facilitate production sharing in Indonesia.

The service link cost depends on the quality of physical infrastructure such as (1) the supply of electricity, (2) the network of highways, ports, and airports, (3) the information and communications technology infrastructure and also the quality of market-supporting institutions such as (1) the assignment and protection of property rights, (2) the enforcement of private contracts, (3) the ease of doing business and the absence of excessive red tape, (4) the consistent and coherent enforcement of laws and regulations at all governmental levels. Production cost savings depend on the cost of labor, capital, and other factors in the host country compared to the home country.

The World Economic Forum (WEF) (2017) surveyed executives to learn about the ease of doing business. For Indonesia, several problems stand out that either increase the service link cost or decrease the production cost savings of producing in Indonesia. In terms of infrastructure, the quality of electricity supply is an outlier. Indonesia's overall competitiveness ranking according to the WEF is 36th out of 137 countries, but its ranking in terms of electricity quality is 86th. In terms of doing business, the two most problematic factors highlighted by executives are corruption and inefficient government bureaucracy. In terms of production costs, Indonesia ranks 133rd out of 137 countries on redundancy costs in the labor market. On average employers need to pay 58 weeks of salary when they dismiss workers. Minimum wage increases have also made labor more expensive. Indonesia also relies heavily on imported capital goods. The weak exchange rate and protectionism increase the rupiah cost of these goods.

Indonesia currently generates electricity using coal and natural gas. Myanmar,

Cambodia and other ASEAN countries have the potential to export hydropower. ${ }^{6}$ Trading hydropower with its neighbors would increase Indonesia's electricity supply, reduce the service link cost, and promote decarbonization.

\footnotetext{
${ }^{4}$ Data on the inward flow of FDI come from the United Nations Conference on Trade and Development. They are available at www.unctad.org.

5 This section focuses on what Kimura and Chen (2018) called the second unbundling. This involves the task-wise division of labor in the machinery industries. Although Indonesia should eventually achieve the third unbundling (the person-wise division of labor via the digital economy), it still has huge potential especially on Java to pursue the second unbundling.

${ }^{6}$ It is important to ensure that dams and other sources of hydropower in developing Asia are safe and that they do not disrupt the local population and environment.
} 
Integrating energy markets in this way requires regulatory and price harmonization and massive infrastructure investment. Public-private partnerships could help to raise funds for infrastructure. ASEAN policymakers could increase investors' confidence by affirming their commitment to reducing carbon emissions and maintaining stable policies. Attracting sufficient capital, designing appropriate incentives, and overcoming other obstacles to energy integration will prove challenging. Researchers and policymakers in ASEAN should focus on resolving these issues (Anbumozhi 2018).

To lower the service link cost and attract FDI, reducing the corruption that the WEF survey highlighted is also important. Corruption in Indonesia has a long history, going back to the Suharto era (1965-1998) and before. Popular discontent with corruption (korupsi), collusion (kolusi) and nepotism (nepotisme), or KKN, also has a long history. Over the last 15 years Indonesia, with the help of the Corruption Eradication Commission, has made progress at reducing corruption. As Indonesia Investments (2017) noted, Transparency International's Corruption Index has improved steadily since 2005. Government leaders need to fight corruption if they want to attract FDI.

According to the World Bank (2018a), Indonesia has also improved government efficiency by allowing electronic processing for imports and online payment of taxes. However, the World Bank ranked Indonesia 144th out of 190 countries in terms of ease of starting a business and 145th out of 190 countries in terms of enforcing contracts. Creating a more business friendly environment in these and other areas would reduce the service link cost and increase FDI in Indonesia.

To increase the production cost savings from fragmentation and thus attract FDI, addressing the labor redundancy costs and rising minimum wages that the WEF survey highlighted is important. Very high severance pay and rising minimum wages are intended to increase economic security for workers. There are better ways to do this though. Greenspan (2003) observed that restrictions on firing workers also reduce firms' willingness to hire workers. In addition, Krugman (1990) has noted that living standards over time depend on worker productivity. If high redundancy costs restrict FDI, they may reduce worker productivity and thus long-run living standards. Hill (2018) also noted that onerous severance pay requirements in Indonesia reduce formal sector employment growth and increase dualism between wealthier formal sector workers and poorer informal sector workers.

Another strategy would be to lower labor costs, attract FDI, and pursue technology spillovers. Once Indonesia receives a critical mass of FDI, industrial agglomeration will take place (Lim and Kimura 2010). Local small and medium-sized enterprises and service sector firms could then develop and become competitive. Workers could also migrate across firms, bringing their human capital with them and dispersing it across the cluster. This would increase output per worker. Economies of scale would accompany the agglomeration. With many firms located close together, firms could source more parts and components locally and could adapt more easily to changes in customer demand and technological requirements. This would lower the service link cost further and attract more FDI.

The ability to obtain technology transfer from FDI depends on the absorptive capacity of Indonesian firms. Urata et al. (2006) found that the intra-firm transfer of managerial technology from Japanese FDI firms to indigenous workers happens more quickly when workers in the host country are better educated. It is not enough to simply provide more education. Rather students need a high quality education in science and math at the secondary school level and scientific training at the university level (see Yusuf et al. 2003). The ability of Indonesian firms to assimilate new technologies depends especially on the 


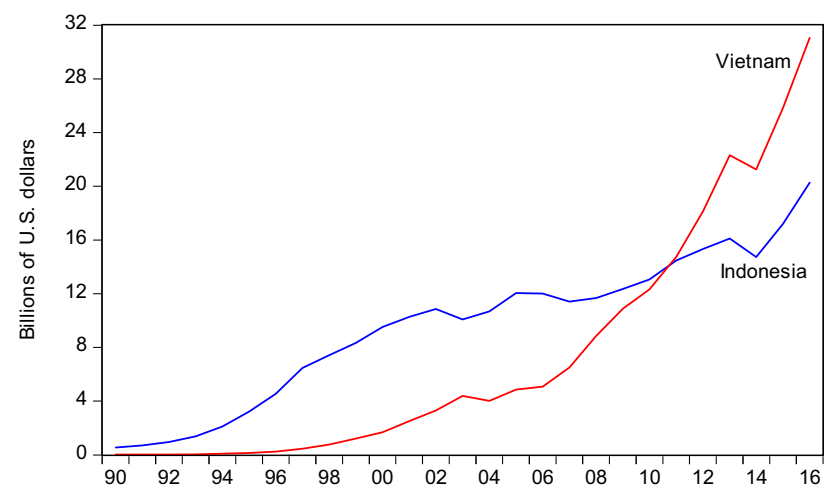

Fig. 3 The value of labor-intensive exports from Indonesia and Vietnam. Notes: Labor-intensive goods come from the following categories: carpets, clothing, fabrics, furniture, knitwear, leather, and yarns. Source: CEPII-CHELEM database

quantity and technical capabilities of local engineers. Scholarships for science and engineering students could thus be helpful.

Importing sophisticated capital goods also plays a role in technology transfer. Yoshitomi (2003) noted that firms and workers in emerging Asia learn by using and reverse-engineering imported capital goods. Lee and Wie (2015), using firm-level data from the Indonesian Manufacturing Survey, found that foreign technology embedded in imported material and FDI caused greater demand for skilled labor in the manufacturing sector. They concluded that importing foreign technology leads to skill-biased technological change in Indonesia.

The World Bank (2018c) and Pane and Pasaribu (2020) discussed how import barriers raise the cost of imported capital goods and parts and components and decreases Indonesia's competitiveness relative to countries such as Vietnam. Promoting free trade could reduce the cost of capital and intermediate goods imports and attract FDI. Indonesia could promote free trade by reducing tariff and non-tariff barriers and by joining free trade agreements such as the Regional Comprehensive Economic Partnership and the Comprehensive and Progressive Agreement for Trans-Pacific Partnership.

\section{Increasing labor-intensive exports through improving human capital and encouraging entrepreneurship}

The discussion above has focused on how Indonesia could attract FDI, assimilate technologies, and export sophisticated products such as electronics goods. It could also benefit from exporting more labor-intensive goods. Indonesia has many lower-skilled workers, and exporting clothing, furniture, and footwear would provide employment for them. Indonesia's exports of manufactures in the past led to learning by doing and technological assimilation. Yoshitomi (2003) noted that entrepreneurs and workers learned new ways of organizing economic activity and acquired new skills. Hill (2018) reported that productivity and wages in Indonesia grew rapidly after it embraced a labor-intensive, export-oriented industrialization strategy.

As Fig. 3 shows, Indonesia has recently lagged behind neighbors such as Vietnam in labor-intensive exports. Since 2009 its export of furniture has declined, while its export of wood has almost doubled. The largest importer of Indonesian wood is China, and China 
uses Indonesian wood to produce furniture. If Indonesia could manufacture more of the furniture and other light manufacturing goods domestically, its workers could gain opportunities to participate in higher value added aspects of production such as design.

How can Indonesia increase its manufacturing base? Many of the strategies discussed above to create a more business friendly environment would help. In addition, it is crucial to invest in human capital and to encourage entrepreneurship.

Human capital investments should begin with good pre-natal care and healthcare and nutrition for the first 1000 days of life. Early malnutrition and stunting hinders learning throughout life (see World Bank 2018b). To help finance these investments, Indonesia could replace general price support programs for fuel consumption with subsidies targeted at the poor and near-poor. General price supports have raised fossil fuel consumption and carbon dioxide emissions, congested roads, reduced the cost advantages for investing in energy efficient technologies, and increased fuel imports and thus energy insecurity (see, e.g., Burke et al. 2017). These funds could be better used investing in the young.

The World Bank (2018b) noted that routine and codifiable jobs are vulnerable in the digital economy. To resist this, it emphasized that education should impart advanced cognitive skills such as complex problem-solving, social skills such as teamwork, and adaptive skills such as reasoning and self-efficacy. Indonesia has performed poorly relative to peers such as Vietnam in imparting skills. In the 2015 Programme for International Assessment (PISA) tests, Vietnam scored 8th out of 72 countries and Indonesia scored 62nd. Vietnam's success in this area is one reason why its labor-intensive exports have far surpassed Indonesia's recently.

There are many obstacles to improving education in Indonesia. As Rosser (2018) discussed, low government investment in education, inadequately trained teachers, an incentive structure that fails to reward good teaching, and excessive government control have all militated against providing a quality education. It is crucial to focus on resolving these and other problems if Indonesia is to be competitive in the twenty-first century. It is also important to be patient, as investments in education may take 15 years or longer to bear fruit (World Bank 2018b).

Even with an educated workforce, entrepreneurship is vital for providing opportunities for workers. Entrepreneurship provides the decision making and initiative needed to transform new ideas into practice and to create new firms that will provide employment for workers (Yoshitomi 2003). Taking steps to improve the business climate and remove red tape, as discussed above, is vital to encouraging entrepreneurship. In addition, the government should survey entrepreneurs and start-up firms to learn the obstacles that they face and the support that they need and should act assiduously on these recommendations.

When exporting, entrepreneurs face costs they do not face when selling domestically. ${ }^{7}$ They incur costs to study market profitability, invest in products tailored to foreign markets, meet country-specific regulatory requirements, maintain distribution networks, ship goods abroad, and pay duties and insurance. It also takes 60 days longer on average for goods to be sold abroad than for goods to be sold domestically. The extra costs and delayed revenues make exporters dependent on external sources of finance. Strengthening bank risk management practices and deepening Indonesia's capital markets are thus important to maintain the flow of credit to entrepreneurs and facilitate exporting.

7 This paragraph draws on Manova (2015). 


\section{Conclusion}

This paper investigates how exchange rates affect the Indonesian economy. Exchange rate exposure equations indicate that both the aggregate stock market and Indonesian banks are exposed to a weakening rupiah. This makes sense since the lion's share of bank loans flow to corporations and since $45 \%$ of corporate debt is denominated in foreign currency. Trade elasticity estimates indicate that a rupiah depreciation would not increase aggregate exports but that a decrease in trading partners' GDPs would cause exports to plummet. Correlation analysis indicates that there are large positive correlations between Indonesia's aggregate export prices and the prices of primary products such as iron, steel, aluminum, natural gas, paper, copper, and rubber and negative correlations between aggregate export prices and the prices of electronics goods and labor-intensive manufacturing goods.

These results imply that Indonesia is exposed to a rise in global risk aversion and a worldwide slowdown. During such a "risk-on" episode, the U.S. dollar tends to appreciate and commodity prices fall. The dollar appreciation (rupiah depreciation) would burden Indonesian corporations that have borrowed in foreign currency and increase risks for Indonesian banks that have loaned to corporations. The fall in the rupiah would not increase exports but the drop in rest of the world income would cause a large drop in exports. The fall in commodity prices would also worsen the terms of trade.

To hedge against this risk, Indonesia should diversify its export base and its trading partners. Exporting manufactured goods could increase Indonesia's resilience to decreases in commodity prices and exchange rate depreciations. Exporting to many countries could reduce the Indonesian economy's exposure to downturns in key markets such as China and the U.S.

In the late 1980s and early 1990s, Indonesia advanced as an exporter of manufacturing goods. By attracting FDI and competing in world markets, workers learned new skills and firms became more dynamic. After the Asian Financial Crisis, however, primary products became ascendant in Indonesia's export basket. Just as an airplane is safer when it has two working engines, Indonesia should cultivate manufacturing exports as a second engine of growth alongside commodity exports.

Acknowledgements I thank an anonymous referee for excellent comments. Any errors are my responsibility.

\section{References}

ADB (Asian Development Bank) (2018) Asian development outlook 2018 update. Maintaining stability amid heightened uncertainty. ADB, Manila

Anbumozhi V (2018) Public-private partnerships for scaling up investments in low carbon energy transition. Paper presented at the 2nd international conference on energy economics, Manila, 20 July

Azis I (2018) Development and shortcomings of Indonesia's financial sector. The role of services in production and international trade: a theoretical framework. In: Volz U, Morgan PJ, Yoshino N (eds) Routledge handbook of banking and finance in Asia. Routledge, London, pp 76-88

Azis I, Thorbecke W (2004) the effects of exchange rate and interest rate shocks on bank lending in indonesia. Econ Finance Indonesia 52(3):279-295

Baiardi D, Bianchi C (2019) At the roots of China's striking performance in textile exports: a comparison with its main Asian competitors. China Econ Rev 54(April):367-389

Barro R (1990) The stock market and investment. Rev Financ Stud 3(1):115-131

BIS (Bank for International Settlements) (2013) Basel III: the liquidity coverage ratio and liquidity risk monitoring tools. Bank for International Settlements, Basel 
Black F (1987) Business cycles and equilibrium. Basil Blackwell, New York

Blanchard O, Ostry JD, Ghosh AR, Chamon M (2015) Are capital inflows expansionary or contractionary? Theory, policy implications, and some evidence. NBER Working Papers 21619, National Bureau of Economic Research, Cambridge, MA

Burke P, Batsuuri T, Yudhistira MH (2017) Easing the traffic: the effects of Indonesia's fuel subsidy reforms on toll-road travel. Transp Res Part A: Policy Pract 105(November):167-180

Chen N-F, Roll R, Ross S (1986) Economic forces and the stock market. J Bus 59(3):383-403

Chinn M (2004) Incomes, exchange rates, and the U.S. trade deficit once again. Int Finance 7(3):451-469

Chinn M (2005) Doomed to deficits? Aggregate U.S. trade flows re-examined. Rev World Econ 141(3):460-485

Dominguez K, Tesar L (2006) Exchange rate exposure. J Int Econ 68(1):188-218

Greenspan A (2003) The Reagan legacy. Speech given at Simi Valley, CA. www.federalreserve.gov. Accessed on 9 April

Haswidi A (2018) Indonesia's currency woes threaten housing recovery' financial times confidential research. www.ft.com. Accessed on 5 Sept

Hill H (2018) Asia's third giant: a survey of the indonesian economy. Econ Rec 94(307):469-499

IMF (International Monetary Fund) (2018) Indonesia 2017 Article IV Consultation. IMF, Washington

Indonesia Investments (2017) Corruption in Indonesia. Weblog, https://www.indonesia-investment s.com/business/risks/corruption/item235. Accessed on 23 June

Jayasinghe P, Tsui AK (2008) Exchange rate exposure of sectoral returns and volatilities: evidence from japanese industrial sectors. Jpn World Econ 20(4):639-660

Jones RW, Kierzkowski H (1990) The role of services in production and international trade: a theoretical framework. In: Jones RW, Krueger AO (eds) The political economy of international trade: essays in honor of Robert E. Baldwin. Blackwell, Cambridge, pp 31-48

Kao C (1999) Spurious regression and residual-based tests for cointegrated regression in panel data. J Econom 90(1): 1-44

Kimura F, Chen L (2018) Value chain connectivity in Indonesia: the evolution of unbundlings. Bull Indonesian Econ Stud 54(2):165-192

Krugman P (1990) The age of diminished expectations: U.S. economic policy in the 1990s. MIT Press, Cambridge, MA

Lee J-W, Wie D (2015) Technological change, skill demand, and wage inequality: evidence from Indonesia. World Dev 67(March):238-250

Lim H, Kimura F (2010) The internationalization of small and medium enterprises in regional and global value chains. ADBI Working Paper No. 231, Asian Development Bank Institute, Tokyo

Liu J, Nissim D, Thomas JK (2007) Is cash flow king in valuations? Financ Anal J 63(2):1-13

Manova K (2015) Global value chains and multinational activity with financial frictions. In: Amador J, di Mauro F (eds) The age of global value chains: maps and policy issues. Center for Economic Policy Research, London, pp 187-200

McElroy M, Burmeister E (1988) The arbitrage pricing theory as a restricted nonlinear multivariate regression model. J Bus Econ Stat 6(1):29-42

Pane D, Pasaribu D (2020) Indonesia's garment industry in crisis. East Asia Forum Weblog. https:// www.eastasiaforum.org/2020/08/10/indonesias-garment-industry-in-crisis/. Accessed on 10 Aug

Ross S, Westerfield R, Jaffe J, Jordan B (2018) Corporate finance. McGraw-Hill, New York

Rosser A (2018) Beyond access: making Indonesia's education system work. Lowy Institute, Sydney

Schwert G William (1990) Stock returns and real activity: a century of evidence. J Finance 45(4):1237-1257

Shapiro M (1988) The stabilization of the U.S. economy: evidence from the stock market. Am Econ Rev 78(5): 1067-1079

Thorbecke W (2018) Investigating ASEAN's electronic and labor-intensive exports. J Asian Econ 55(April):58-70

Thorbecke W (2019) How oil prices affect East and Southeast Asian economies: evidence from financial markets and implications for energy security. Energy Policy 128:628-638

Thorbecke W, Salike N (2020) Export sophistication and trade elasticities. J Asian Econ Integr 2:1-20

Urata S, Matsuura T, Wei Y (2006) International intrafirm transfer of management technology by japanese multinational corporations. RIETI Discussion Paper 06-E-006, Research Institute of Economy, Trade and Industry, Tokyo

Velinov A, Chen W (2015) Do stock prices reflect their fundamentals? New evidence in the aftermath of the financial crisis. J Econ Bus 80(C):1-20

World Bank (2018a) Doing business. World Bank, Washington

World Bank (2018b) World development report. The changing nature of work. World Bank, Washington 
World Bank (2018c) Indonesian economic quarterly December 2018. Strengthening competitiveness. World Bank, Washington

World Bank (2020) Indonesia economic prospects: the long road to recovery. World Bank, Washington

World Economic Forum (2017) Global competitiveness report 2017-2018. World Economic Forum, Geneva Yoshitomi M (2003) Post crisis development paradigms in Asia. Asian Development Bank Institute, Tokyo

Yusuf S, Anjum Altaf M, Eichengreen B, Gooptu S, Nabeshima K, Kenny C, Perkins D, Shotten M (2003) Redrawing the international boundary of the firm in East Asia: the evolution of international production networks. In: Yusuf S (ed) Innovative East Asia: the future of growth. World Bank, Washington, DC, pp 271-324

Publisher's Note Springer Nature remains neutral with regard to jurisdictional claims in published maps and institutional affiliations. 